\title{
A programme of global pacification: US counterinsurgency doctrine and the biopolitics of human (in)security
}

Security Dialogue

42(6) 517-535

(C) The Author(s) 2011

Reprints and permission: sagepub. co.uk/journalsPermissions.nav DOI: $10.1177 / 0967010611423268$ sdi.sagepub.com (SAGE

\section{Markus Kienscherf}

Department of Sociology, Graduate School of North American Studies, Free University Berlin, Germany

\begin{abstract}
This article argues that US counterinsurgency doctrine forms a programme of both liberal rule and liberal war whose ultimate purpose is the pacification of recalcitrant populations and their eventual (re)integration into the networks of liberal governance. Designed to promote 'safe' forms of life while eradicating 'dangerous' ones, the doctrine constitutes a response to both the biopolitical problematization of human (in)security and the geostrategic problematization of US national security. Counterinsurgency aims to harness sociocultural knowledge in order to conduct a form of triage between elements of targeted populations. It also seeks to inscribe the divisions on which such a triage is based into space by means of practices that derive from earlier methods of imperial policing. Ultimately, counterinsurgency's production and implementation of a biopolitical differentiation between 'safe' and 'dangerous' human lives is likely not only to reinforce existing societal divisions within targeted populations but also to create new global, regional and local divisions and to generate resistance to what many people will always view as imperial domination. The societal divisions and resistance engendered by counterinsurgency may reinforce Western problematizations of insecurity and hence lead to further counterinsurgency campaigns in the future. Counterinsurgency doctrine is thus not so much a programme of peace and stability as one of spatially and temporally indeterminate pacification.
\end{abstract}

\section{Keywords}

counterinsurgency, human security, biopolitics, liberalism, imperialism

\section{Introduction}

On 13 February 2010, US, Canadian, British, Danish and Estonian forces launched Operation Moshtarak in Afghanistan's Helmand province - the first major assault on Taliban insurgents since US President Barack Obama's decision to deploy an additional 30,000 troops in the country (BBC, 2010a). Operation Moshtarak (which means 'together' in the local Dari language) differed from 
earlier attacks on Taliban strongholds in that, contrary to the common military practice of trying to maintain an element of surprise, the local population was informed about the impending offensive. Several weeks prior to the launch of the operation, Afghan government officials and Western troops sought to persuade locals to throw in their lot with the Afghan central government and its Western backers (Gardner, 2010). Although the first days of the operation were overshadowed by reports of civilian casualties, the operation was said to have been designed with the express purpose of avoiding civilian deaths (BBC, 2010b). US Chairman of the Joint Chiefs of Staff Admiral Mike Mullen (2010) asserted that Operation Moshtarak was more than just a conventional military offensive:

There's great focus on - and [Afghan] President Karzai has made this point, and I think this is critical - on having - we would like to have no civilian causalities. I mean, this is focused on the people. This is not focused on the Taliban. And it is a strategy that will not just clear the area, but that will hold it and then build right behind it. So there's a civilian component here, and there's a local governance piece, which is going to be installed immediately, as well.

Operation Moshtarak was meant to showcase "the new "counter-insurgency" approach of US and NATO commander Gen Stanley McChrystal' (BBC, 2010a; see also McChrystal, 2009). ${ }^{1}$ The operation was based on a counterinsurgency-style clear-hold-build model that was aimed at providing security, development and good governance to the local population, rather than merely killing insurgents.

However, as Operation Moshtarak progressed and US-led NATO forces seized the largely rural area of Marja, ${ }^{2}$ Robert Watkins, deputy special representative for the UN secretary-general, openly criticized what he saw as the 'militarization of aid' in Afghanistan, stating that 'we do not wish to be part of that process because we would not want to have the humanitarian activities we deliver to be linked with military activity' (quoted in Tran, 2010). Such isolated criticisms notwithstanding, humanitarian aid and development efforts have become closely tied to (mostly Western) security concerns. In fact, a growing number of academics, policymakers and aid workers agree that security and development are interconnected (see Duffield, 2005, 2007, 2008, 2010; Hettne, 2010; Stern and Öjendal, 2010).

According to Mark Duffield (2008: 146), security and development have merged into a potentially global strategy for the management of at-risk and risky populations - a biopolitical containment strategy 'that seek[s] to restrict or manage the circulation of incomplete and hence potentially threatening life' (see also Duffield, 2003, 2005, 2007, 2010). Duffield even goes so far as to assert that 'liberal practices of development traditionally associated with NGOs have been rediscovered as essentially civilian forms of counterinsurgency' (Duffield, 2008: 157; see also Slim, 2004). The attempt to control and contain flows of risky life is also one of the major objectives of the global pacification efforts that, according to Michael Dillon and Julian Reid (2009), characterize 'the liberal way of war'. What is more, 'the liberal way of war' is inextricably intertwined with 'the liberal way of rule' and its biopolitical 'commitment to making life live' (Dillon and Reid, 2009: 11).

Indeed, the relevance of Michel Foucault's ideas of biopower and biopolitics to critical analyses of 'the liberal problematic of security' has been amply demonstrated (Evans, 2010: 414, 428; see also Dillon and Neal, 2008; Dillon and Reid, 2009; Duffield, 2007; Edkins et al., 2004). These largely theoretical analyses, however, should be complemented by more empirical interrogations of the actual governmental programmes by means of which biopolitical imperatives are supposed to be implemented on the ground. In other words, we should also attend to the design and deployment of specific governmental rationalities meant to respond to a biopolitical problematization of human (in)security. 
This article deals with one such programme. It sets out to show that US counterinsurgency doctrine is a rationality of both rule and warfare whose ultimate purpose is the pacification of recalcitrant populations and their eventual (re)integration into the networks of liberal governance. First, the article will argue that US counterinsurgency doctrine forms a response to both the biopolitical problematization of 'human security' and the geostrategic problematizations of US national security. In a security environment said to be defined by the global circulation of threats emanating from so-called ungoverned spaces, the imperatives of human security and the goals of US national security are frequently supposed to coincide. Second, the article will demonstrate how counterinsurgency doctrine aims to harness sociocultural knowledge in order to conduct a form of triage between elements of targeted populations, and how the divisions on which such a triage is based are inscribed into space by means of practices that derive from earlier methods of imperial policing. Ultimately, counterinsurgency's production and implementation of a biopolitical differentiation between 'safe' and 'dangerous' life is likely not only to reinforce existing societal divisions within targeted populations, but also to create new global, regional and local divisions and to generate resistance to what many people will always view as imperial domination. The societal divisions and resistance engendered by counterinsurgency may reinforce Western problematizations of insecurity and hence lead to further counterinsurgency campaigns in the future. Counterinsurgency doctrine is thus not so much a programme of peace and stability as one of spatially and temporally indeterminate pacification.

\section{Counterinsurgency revamped}

We are opposed around the world by a monolithic and ruthless conspiracy that relies primarily on covert means for expanding its sphere of influence - on infiltration instead of invasion, on subversion instead of elections, on intimidation instead of free choice, on guerrillas by night instead of armies by day. (Kennedy, 1961: 336)

John F. Kennedy's obsession with guerrilla warfare is well documented. Roger Hilsman (1967: 413), a key aide and foreign policy adviser to Kennedy, wrote that one of the first questions Kennedy put to his aides after his inauguration as president was, 'What are we doing about guerrilla warfare?' Kennedy took a strong personal lead in pushing for a programme aimed at countering guerrilla warfare in particular and what he saw as a 'monolithic and ruthless conspiracy' in general (see Blaufarb, 1977; McClintock, 1992; Shafer, 1988). Kennedy’s obsession immediately led to a flurry of activities at all levels of the US national security apparatus: seminars and courses on counterinsurgency; major efforts at bureaucratic restructuring; and the frenetic formulation of new policies and doctrine. In 1962, the Kennedy administration promulgated its Overseas Internal Defense Policy (US Government, 1962) - a comprehensive counterinsurgency programme that sought to merge security and development into a coherent policy geared towards containing the threat of communism. Yet, following the US defeat in Vietnam, counterinsurgency quickly faded into doctrinal oblivion and US military strategy shifted back to more conventional concerns.

These days, however, counterinsurgency (COIN) is once again fashionable among policymakers, members of the armed forces, Pentagon officials and civilian academics. Indeed, counterinsurgency is now widely touted not only as an instrument for defeating Iraqi or Afghan insurgents but also as a panacea for fighting global terrorism (Cassidy, 2006; Kilcullen, 2005, 2009; Nagl, 2007; for a critique, see Bacevich, 2010). So, what is counterinsurgency all about? 
The new U.S. Army/Marine Corps Counterinsurgency Field Manual, which was introduced in 2006 and published by the University of Chicago Press in 2007 (I will refer to the latter edition throughout this article), defines insurgency as 'an organized, protracted politico-military struggle designed to weaken the control and legitimacy of an established government, occupying power, or other political authority while increasing insurgent control'. Counterinsurgency in turn is defined as 'military, paramilitary, political, economic, psychological, and civic actions taken by a government to defeat insurgency' (US Department of the Army, 2007: 2). What becomes immediately obvious is that counterinsurgency doctrine ought to be understood as a programme of both rule and warfare that seeks to assemble humans, technologies, tactics and modes of knowledge (production) into an ambiguous machine geared towards pacifying ungoverned spaces and populations that more often than not tend to be located in the post-colonial south.

This pacification effort hinges on providing security to the local population while (re)building the politico-economic infrastructure that would ultimately enable the so-called host nation to govern itself. Moreover, the provision of security and development is supposed to occur against the backdrop of an overall battle over perceptions to be waged through effective information operations (US Department of the Army, 2007). According to the current field manual, 'the primary objective of any COIN operation is to foster development of effective governance by a legitimate government' (US Department of the Army, 2007: 37). What is thus at stake in counterinsurgency is government.

According to Michel Foucault (2000: 341), government aims to act on somebody else's actions - or, in Foucault's own words, 'to structure the possible field of action of others'. Government involves knowledge, expertise and representations concerning both the objects and the activity of government, as well as technologies, techniques, instruments and tactics by means of which the day-to-day business of governing is actually conducted (see Dean, 1999; Larner and Walters, 2004; Rose and Miller, 1992). Government is thus characterized by the interrelations between rationalities or programmes - 'deliberate and relatively systematic forms of thought' - and specific 'regimes of practices' (Dean, 1999: 32, 27, 28; see also Rose and Miller, 1992; Miller and Rose, 2008). Government therefore operates within the frame of what Foucault termed 'governmentality' and constitutes a mode of power that cuts across 'the problematics of consensus and will on the one hand and conquest and war on the other' (Lemke, 2000: 4; see also Foucault, 2003, 2007).

Military theorist Carl von Clausewitz (1976: 83) famously described war as 'an act of force to compel our enemy to do our will'. But, in contemporary unconventional warfare the use of force is just one particular channel for imposing one's will on the enemy. In what Thomas X. Hammes (2006: 207-8) calls 'fourth-generation warfare' (4GW), which he describes as 'an evolved form of insurgency', war has shifted from the industrial-scale destruction of one's opponent's armed forces to undermining the political will of enemy decisionmakers through both violent and nonviolent means. In fact, war can no longer be clearly distinguished from nonviolent forms of imposing one's will on others. Likewise, the traditional divide between crime and war and the concomitant division between domestic public safety and foreign defence has become increasingly fuzzy (see Feldman, 2004). Thus, what Anthony Giddens (1987) called the internal pacification of society has bled into the defence against external threats, and vice versa. Indeed, as Hardt and Negri (2004: 7) suggest, 'war seems to have seeped back and flooded the entire social field'.

When Foucault (2003: 15) inverted Clausewitz's (1976: 99) famous dictum that war is 'a continuation of political intercourse, carried on with other means' in order to frame the problematic of political power as the 'continuation of war by other means', he sought to draw out the war-like force relations that persist even within internally pacified societies. Yet, Foucault's later focus on 
'government' was a move both beyond the juridical conception of power as repression and his own earlier bellicose notion of power as domination (Dean, 1999). In Foucault's (2000: 341) own words:

The relationship proper to power would therefore be sought not on the side of violence or of struggle, nor on that of voluntary contracts (all of which can, at best, only be instruments of power) but, rather, in the area of that singular mode of action, neither warlike nor juridical, which is government.

Government in the Foucauldian sense of acting on somebody else's actions thus always consists of and constantly shifts between relations of both coercion and consent. In counterinsurgency, this tension between coercion and consent also operates across the divide between internal pacification and external defence. Combining the use of force with the engineering of consent through development and so-called information operations, counterinsurgency seeks to internally pacify foreign societies in order to check the global flow of threats and thereby also secure already pacified societies.

Indeed, counterinsurgency doctrine has been presented not only as a fix to the steadily deteriorating post-invasion security situations in Iraq and Afghanistan, but also as a much more general programme aimed at transforming US security capabilities in the face of a specific biopolitical problematization of human (in)security. But, what are the referent objects of this problematization of security and danger?

\section{Human security and biopolitical imperialism}

The post-Cold War period has witnessed a conceptual shift from traditional state-centred security to so-called human security (Commission on Human Security, 2003; see also De Larrinaga and Doucet, 2008; Duffield, 2008, 2010; Hettne, 2010; Manwaring, 2005; Stern and Öjendal, 2010; Makaremi, 2010). Human security is broadly defined as processes for protecting 'people from critical (severe) and pervasive (widespread) threats and situations' and for 'creating political, social, environmental, economic, military and cultural systems that together give people the building blocks of survival, livelihood and dignity' (Commission on Human Security, 2003: 4). The notion of human security is deeply biopolitical in that it seeks to promote species-life and protect it from threats arising from species-life itself (De Larrinaga and Doucet, 2008; Duffield, 2008).

Moreover, as human security is now frequently presented as a 'response to the narrative of global chaos', it also provides impetus to a new militarized interventionism (Makaremi, 2010: 108). Mary Kaldor, one of the most vociferous proponents of human security, states that "'bad neighborhoods" like the Horn of Africa, the Upper Nile, the Middle East, the Caucasus, and Central Asia' provide breeding grounds for violence that could spread into the world's 'good neighborhoods', 'through refugees and displaced persons, through transnational criminal activities; and through polarizing activities' (Kaldor and Beebe, 2010: 37; see also Glasius and Kaldor, 2005; Kaldor, 1999). There is a considerable overlap between Kaldor's global distribution of 'bad neighborhoods' and the Pentagon's 'arc of instability' that stretches from Africa through the Middle East all the way to Central and Southeast Asia. Thomas Barnett's (2004) idea of the 'Gap' is even more extensive and also includes wide swathes of Central America and the Caribbean. Yet, the fundamental logic remains the same: a division of the globe into an integrated metropolitan system of stable states, on the one hand, and a kind of peripheral global borderlands marked by failed and failing states, violence, crime, corruption, etc., on the other.

Counterinsurgency doctrine is held up as an effective remedy to the global spread of violence and instability. General David Petraeus, one of the chief architects of US counterinsurgency 
strategy, told Mary Kaldor that counterinsurgency and human security are pretty much the same because both cluster around the 'two key principles' of providing security and vital services to the population and separating 'the reconcilables from the irreconcilables' (quoted in Kaldor and Beebe, 2010: 68). Although she comes out in support of the US military's recent move towards counterinsurgency, Mary Kaldor, however, maintains that there remain significant differences between counterinsurgency and human security:

In counterinsurgency, human security, or population security, is a tactic, not a strategy. The end goal is not the security of Afghans or Iraqis - that is a means to an end. The end goal is the defeat of America's enemies, a point that General Petraeus and others frequently repeat. (Kaldor and Beebe, 2010: 73)

In effect, Kaldor argues that counterinsurgency is not biopolitical enough, because it remains an instrument of US geostrategy.

Yet, most proponents of counterinsurgency doctrine suggest that in the face of global circulations of violence and instability US geostrategic goals largely overlap with the pursuit of human security. For instance, in the Introduction to the University of Chicago Press edition of the Counterinsurgency Field Manual, Sarah Sewall (2007: xlii), director of Harvard's Carr Human Rights Center, argues that with the disappearance of the stabilizing framework of the Cold War, the major security challenge for the United States now consists in 'buttressing multiple failing state structures to legitimize the interstate system'. According to Sewall (2007: xxxvii), this requires (re)building the capacities of fledgling states through a combination of military and civilian means:

U.S. unwillingness to govern other nations is, in this account, a fatal national flaw. The field manual stresses the importance of effectively employing nonmilitary power. It is not a responsibility that can be left to a beleaguered host nation. Counterinsurgents must harness the ordinary administrative functions to the fight, providing personnel, resources, and expertise.

For Sewall (2007: xlii), in order to meet the 'strategic challenge' of stabilization, the United States has to get into the business of governing nations that are deemed unable to govern themselves.

Moreover, Mark Duffield (2008: 149) points out that 'while [human security] prioritizes the security of people rather than states, it privileges the state as vital for providing the public goods that constitute human security'. Indeed, the discourse of human security has it that if certain states are unable to provide security for their populations, other more powerful states have a moral duty to intervene, secure the targeted population and develop the host nation's capacities so that it may eventually be able to secure its own population. In fact, the discourse of human security both legitimizes and entails a biopolitical form of imperialism. This form of imperialism is driven not so much by limited national geopolitical ambitions (although they still play a major role) as by the unlimited aim of securing humanity from its own inherent threats. Since its objectives are boundless, biopolitical imperialism's campaigns of pacification also tend to be both spatially and temporally indeterminate. And counterinsurgency doctrine forms a concrete governmental programme of biopolitical imperialism insofar as it is presented as a therapy for particular pathologies of insecurity and danger.

\section{A 'therapy' for ungoverned spaces}

So-called ungoverned spaces - also often referred to as 'failed', 'failing' or 'weak' states - and their unruly populations are among some of the most significant referent objects of discourses of both human security and US national security (Kilcullen, 2005, 2009; Sewall, 2007). 
The 2010 Quadrennial Defense Review Report, which will be the chief blueprint for US military planning and budgetary allocations for the next couple of years, asserts that 'the changing international environment will continue to put pressure on the modern state system, likely increasing the frequency and severity of the challenges associated with chronically fragile states' (US Department of Defense, 2010: 32). In this environment, the US military can no longer simply rely on its formidable conventional arsenal but must develop the capabilities to mount a series of low-intensity operations across the global south:

The wars we are fighting today and assessments of the future security environment together demand that the United States retain and enhance a whole-of-government capability to succeed in large-scale counterinsurgency (COIN), stability, and counterterrorism (CT) operations in environments ranging from densely populated urban areas and mega-cities, to remote mountains, deserts, jungles, and littoral regions.... Accordingly, the U.S. Armed Forces will continue to require capabilities to create a secure environment in fragile states in support of local authorities and, if necessary, to support civil authorities in providing essential government services, restoring emergency infrastructure, and supplying humanitarian relief. (US Department of Defense, 2010: 43)

In this context, counterinsurgency forms a particularly significant programme insofar as it is designed to cut across the divide between civilian assistance and military intervention in order to address especially problematic cases of state failure. Indeed, counterinsurgency seems to combine what Duffield (2010) calls 'the liberal way of development' with what Dillon and Reid (2009) call 'the liberal way of war'. The liberal way of development seeks to foster 'adaptive patterns of household and communal self-reliance in the global south', while the liberal way of war is aimed at securing global life itself from those 'patterns of self-reliance' that are viewed as threats to global (liberal) life (Duffield, 2010: 55-6, 68; Dillon and Reid, 2009).

Counterinsurgency is supposed to rid particular regions of 'forms of radical autonomy and emergence [that] are deemed to be a risk to the system as a whole', while establishing and promoting modes of 'adaptive self-reliance' that are viewed as safe (Duffield, 2010: 68). The latter task is often relegated to nongovernmental and intergovernmental organizations that are expected to operate under the military umbrella of what the Counterinsurgency Field Manual calls 'unity of effort':

All organizations contributing to a COIN operation should strive, or be persuaded to strive, for maximum unity of effort. Informed, strong leadership forms the foundation for achieving it. Leadership in this area focuses on the central problems affecting the local populace. A clear understanding of the desired end state should infuse all efforts, regardless of the agencies or individuals charged with their execution. (US Department of the Army, 2007: 57)

Counterinsurgency's reliance on a deeply biopolitical problematization of security and danger as well as its commitment to eradicating risky forms of life while promoting safe ones are best illustrated by the writings of David Kilcullen, former senior counterinsurgency adviser to General Petraeus. Kilcullen (2009: 35-38) argues that international terrorist groups, most notably Al-Qaeda, 'opportunistically exploit existing breakdowns in the rule of law, poor governance, or pre-existing conflict. Terrorist infection is thus part of the social pathology of broader societal breakdown, state weakness, and humanitarian crisis'. Although Kilcullen makes a number of points about terrorism in general, much of his discussion centres on Al-Qaeda, which he considers to be at the heart of a globalized insurgency against the West. What he calls the 'accidental guerrilla syndrome' sets in 
with the 'infection' of ungoverned spaces by Al-Qaeda. It then proceeds to the 'contagion phase', in which Al-Qaeda uses these safe havens to spread propaganda and launch terrorist attacks. In the 'intervention phase', external forces, most likely Western powers led by the United States, decide to take military action. This leads to the so-called rejection phase, in which the local population rejects the foreign intervention and enters into alliance with Al-Qaeda:

Again, I use medical analogy advisedly here. The rejection phase looks a lot like a social version of an immune response in which the body rejects the intrusion of a foreign object, even one (such as a pin in a broken bone or a stent in a blocked blood vessel) that serves an ultimately beneficial purpose.

Kilcullen's use of medical tropes is highly illustrative. Indeed, processes of state failure are often presented in terms of pathology. Medical tropes shift the terms of debate from the political to the ultimately technocratic terrain of fixing social pathologies through the outside intervention of agents whose superior expertise and superior values are taken for granted (McFalls, 2010: 318-19). Any debate about whether to intervene in the first place is thereby effectively forestalled - the only debate that is still possible is one about the 'how' of intervention. This holds also true for Kilcullen's The Accidental Guerrilla. Even though Kilcullen acknowledges that outside interventions may well exacerbate processes of radicalization, he fails to question the utility of intervention per se. He merely concerns himself with devising politico-military instruments that do not feed the 'accidental guerrilla syndrome'. In fact, Kilcullen takes the necessity of outside intervention for granted, because he assumes that something has to be done about 'terrorist infection'. He does not ask the question as to whether the initial 'infection' might have been an 'immune response' to earlier Western interference.

Kilcullen's arguments about the growth of cancerous terror cells in ungoverned spaces are profoundly biopolitical. In his analysis of the 'technical armature and rhetoric of counterinsurgency' in Iraq, Derek Gregory (2010: 277) suggests that 'the emphasis on danger, or on what Foucault called "dangerousness", is vital to the development of a martial biopolitics'. What Gregory calls 'martial biopolitics' is nothing but a global liberal strategy of pacification and stabilization geared towards securing humanity from threats emanating from within humanity (Dillon and Reid, 2009). These threats are inevitably problematized in terms of pathologies and therapies:

Every account of life is therefore contoured by its allied discourse of danger, every account of order is contoured by an account of the disorder which threatens it. The biopolitics of liberal rule and war differs only in the account that it gives of ordered and disordered life and is self-endangering. To employ a medical term which therefore fits this condition of rule precisely, the emergency of emergence requires a form of global triage. Global triage specifies who gets what treatment, where, when and how. Some of that treatment - a lot of that treatment - is directly and indirectly lethal. (Dillon and Reid, 2009: 89-90)

Counterinsurgency is thus envisaged as a specific therapeutic programme for the actual implementation of 'global triage'. This is exactly what Kilcullen suggests. He contends that the 'accidental guerrilla syndrome' can be countered by way of a global therapeutic strategy aimed at extending stable governmental structures into ungoverned spaces while disrupting terrorist networks - what he calls 'counterinsurgency plus' (Kilcullen, 2009; see also Kilcullen, 2005). This professedly benevolent strategy, however, inevitably entails the killing of both actual and suspected insurgents and terrorists - as well as, potentially, scores of innocent civilians.

Yet, counterinsurgency not only centres on a strategy of global triage but also seeks to triage targeted populations. The authors of the current field manual maintain that successful counterinsurgency efforts pivot on differentiating between an active minority supporting the insurgency, an 
active minority opposing the insurgency, and a neutral or passive majority that can swing either way (US Department of the Army, 2007: 36). The main objective of the so-called populationcentred or 'hearts and minds' variant of counterinsurgency is then to convince the passive majority to throw in their lot with the counterinsurgents.

However, in order to achieve the ultimate goal of winning over the majority of a targeted population, soldiers and marines require a thorough understanding of a host nation's culture and society. Apart from acting as soldiers, policemen, relief workers and spin doctors, soldiers and marines are also expected to become amateur social scientists, capable of producing knowledge not only about the insurgents but also about all aspects of the society in which they operate:

Intelligence in COIN is about people. U.S. forces must understand the people of the host nation, the insurgents, and the host-nation government. Commanders and planners require insight into cultures, perceptions, values, beliefs, interests and decision-making processes of individuals and groups.... All Soldiers and Marines collect information whenever they interact with the populace (US Department of the Army, 2007: 80).

We will now turn to some of the modes of knowledge (production) that are supposed to render the terrain - or rather the targets - of counterinsurgency intelligible.

\section{Mapping the 'human terrain'}

Current doctrine was shaped not only by members of the armed forces but also by civilian academics, above all social scientists. The most prominent of them, cultural anthropologist Montgomery McFate (2005b: 47), co-author of the field manual's chapter on intelligence, regular contributor to military publications and chief scientific consultant with the US Army's Human Terrain System, argues:

Understanding foreign cultures and societies has become a national security priority. The more unconventional the adversary, the more we need to understand their society and underlying cultural dynamics. To defeat non-Western opponents who are transnational in scope, nonhierarchical in structure, clandestine in their approach, and operate outside of the context of nation-states, we need to improve our capacity to understand foreign cultures and societies.

In another article, published in Military Review, McFate (2005a: 24) deplores anthropology's 'brutal process of self-flagellation' and demands that the discipline should accept its role as 'a warfighting discipline':

Once called 'the handmaiden of colonialism,' anthropology has had a long and fruitful relationship with various elements of national power, which ended suddenly following the Vietnam War. The strange story of anthropology's birth as a warfighting discipline, and its sudden plunge into the abyss of postmodernism, is intertwined with the U.S failure in Vietnam. The curious and conspicuous lack of anthropology in the national-security arena since the Vietnam War has had grave consequences for countering the insurgency in Iraq, particularly because political policy and military operations based on partial and incomplete knowledge are often worse than none at all.

When, after initially successful invasions, the United States became embroiled in protracted insurgencies in both Iraq and Afghanistan, and US armed forces realized that they lacked the linguistic and cultural competence for understanding the 'operational environment', 'culture-centric 
warfare' became something of a mantra among officers and civilian security experts (Clemis, 2009; Kipp et al., 2006; McFate, 2005a,b; McFate and Jackson, 2006; Renzi, 2006; see also Kienscherf, 2010).

From 2005, US armed forces have endeavoured to incorporate sociocultural knowledge and expertise into both doctrine and force structure. The 2006 Counterinsurgency Field Manual's chapter on intelligence, which was co-authored by McFate, is peppered with social-scientific terms - such as 'social networks', 'roles and statuses', 'social norms', 'taboo', 'culture', 'identity', 'narratives', 'myths', 'beliefs', 'ideologies' - that one would hardly expect to find in a military field manual (US Department of the Army, 2007: 79-135). ${ }^{3}$ The manual also contains an appendix entitled 'Social network analysis and other analytical tools' (US Department of the Army, 2007: 305-33). In fact, the observation that 'intelligence in COIN is about people', that successful operations require a thorough understanding of the human terrain, is constantly reiterated throughout the manual.

Between 2005 and 2006, the identified general need for sociocultural knowledge in counterinsurgency operations and the particular absence of such expertise in the ongoing campaigns in Iraq and Afghanistan led to the launch of the so-called Human Terrain System. This programme was 'specifically designed to address cultural awareness shortcomings at the operational and tactical levels by giving brigade commanders an organic capability to help understand and deal with "human terrain" - the social, ethnographic, cultural, economic, and political elements of the people among whom a force is operating' (Kipp et al., 2006: 9). The Human Terrain System aims to embed Human Terrain Teams consisting of between five and nine members into military units. These Human Terrain Teams are to be 'composed of individuals with social science and operational backgrounds that are deployed with tactical and operational military units to assist in bringing knowledge about the local population into a coherent analytical framework and build relationships with the local power-brokers' (Finney, 2008: 2). Human Terrain Teams combine social-network analysis with the geospatial analysis of human and physical geography in an effort to render the sociocultural environment of insurgency intelligible, so that the military can differentiate between active supporters of the insurgency, a passive majority, and active supporters of the host-nation government and its foreign backers (Finney, 2008; Kipp et al., 2006; US Department of the Army, 2007: $36,305-33)$.

However, a growing number of anthropologists firmly oppose what they see as 'the weaponization of anthropology' (Feldman, 2009; González, 2007, 2009a,b; Sahlins, 2009). In 2007, a group of anthropologists set up the Network of Concerned Anthropologists to 'take collective action and produce a statement of our objections to developing trends in the militarization of anthropology' (González et al., 2009: 18). And in October 2009, the American Anthropological Association's Commission on the Engagement of Anthropology with the US Security and Intelligence Communities (CEAUSSIC) unequivocally stated its disapproval of the participation of anthropologists in military operations (Albro et al., 2009).

Moreover, according to David Ucko (2009), the actual on-the-ground deployment of Human Terrain Teams in Iraq and Afghanistan proved to be fraught with difficulties. First of all, Ucko (2009: 166) maintains that the use of civilian Human Terrain Teams cannot solve the long-term problems associated with an 'absence of an equivalent capability within the existing force structure' - that is to say, the lack of linguistic and cultural skills among the military's own specialist civil affairs personnel. Second, owing to the scarcity of 'qualified volunteers', the teams had to be 'placed at the brigade level rather than at the battalion or company level, where they might have had a greater impact'. Lastly, Ucko holds that since the members of Human Terrain Teams were often poorly trained and 'the managerial practices and protocols governing their use and activity in a war zone were at times undefined', they only produced knowledge of 'varied quality'. 
The Human Terrain System was designed to enable the military to triage between different levels of risk so that modes of both lethal and non-lethal targeting might be adapted accordingly. As Marshall Sahlins puts it, 'the principal role of academics in the service of counterinsurgency is to develop the human intelligence (HUMINT) that will allow a triage between those elements of the population to be attacked (or assassinated) and those it would be better not to - in brief, sophisticated targeting' (Sahlins, 2009: vi; emphasis added).

In counterinsurgency, sociocultural knowledge thus serves the purpose of facilitating a triage within targeted populations that have already been singled out through the global triage of biopolitical liberal rule (Dillon and Reid, 2009). The objectives of biopolitics - namely, promoting species-life and securing it from threats arising from within species-life-entail 'modes of discrimination exercised at the level of the biological life of individuals and populations which are explicitly as well as implicitly racialized' (Dillon and Reid, 2009: 133). However, liberal biopolitics cannot openly profess to privilege some aspects of the species over others purely on the basis of race:

Liberal biopolitics had therefore somehow to elide the ways in which all biopolitically driven regimes, including those at one time of liberal imperialism itself, are disposed to favour some aspects of the species over others, as a necessary consequence of seeking to promote the life of the species. (Dillon and Reid, 2009: 49)

In other words, liberal governance can no longer triage between 'safe' and 'dangerous' species-life purely on racial grounds. Yet, the notion of culture, even if it remains implicitly racialized, is not nearly as politically suspect as the category of race. As Brad Evans (2010: 427) puts it, 'racism is not what it used to be. Cultural fitness has now replaced biological heritage to contour the new lines of political struggle'.

A number of critics suggest that the use of sociocultural knowledge in counterinsurgency amounts to a new form of Orientalism (see Feldman, 2009; Gregory, 2008; Kienscherf, 2010). In its classical sense, Edward Said's (1979) term Orientalism describes the complex and ambiguous historical interrelations between the production of knowledge about spaces and populations construed as Oriental and the actual imperial project of establishing Western control over these spaces and populations. Montgomery McFate's demand that anthropology should once again shoulder its responsibilities as a 'warfighting' discipline 'ultimately amounts to saying that the discipline of anthropology should once again turn into a machine for the production of Orientalist discourse something anthropologists have struggled against for many decades' (Kienscherf, 2010: 135; see McFate, 2005a: 24).

In counterinsurgency, sociocultural knowledge about the Other ultimately serves to identify the circulation and enable the targeting of threatening species-life and thereby ends up producing and reinforcing both the conceptual and the physical borders between 'us' and 'them':

The emphasis on cultural difference - the attempt to hold the Other at a distance while claiming to cross the interpretive divide - produces a diagram in which violence has its origins in 'their' space, which the cultural turn endlessly partitions through its obsessive preoccupation with ethno-sectarian division, while the impulse to understand is confined to 'our' space, which is constructed as open, unitary, and generous. (Gregory, 2008: 11)

Moreover, the conceptual production and mapping of endlessly partitioned, internally divided and inherently dangerous spaces and populations bleeds into the actual physical division of these spaces and populations (Gregory, 2010). 


\section{Securing and controlling the 'human terrain'}

Designing the physical environment in such a way as to make it possible to control flows of people and resources plays a fundamental part in the provision of security:

The logic of 'security' ... presupposes that the danger is already inside, presented by a population in which subversive elements exist. The relation that 'security' implies between 'inside' and 'outside', as well as between military and police action, is ambiguous.... 'Security' conceives new spatial practices and arrangements. It erects barriers and channels and rechannels the flow of people and resources through space. According to the logic of security, only a constantly configured and reconfigured environment is a safe environment (Weizman, 2007: 106-7).

Counterinsurgency doctrine is designed to straddle the divide between policing and war-fighting, in order to counter the complex threat of insurgents hiding among civilian populations. I have already discussed the Orientalist modes of knowledge (production) that counterinsurgents rely on in their attempts to differentiate between elements of the population. In examining some of the 'spatial practices and arrangements' deployed in counterinsurgency, I will now show that the actual provision of security is based on efforts to control the movement of people and resources in space - efforts that derive from much older imperialist practices (Weizman, 2007: 107).

Attempts to control flows of people and resources frequently take the form of border regimes. Besides demarcating territory, borders are complex assemblages of tactics, technologies and forms of knowledge (production) that serve as instruments for tracking, targeting and managing the circulation of people and goods. Thus, border assemblages are best described as sorting mechanisms aimed at distinguishing flows whose mobility needs to be facilitated from those that need to be interdicted (Lyon, 2008; Salter, 2005, 2008a,b).

In counterinsurgency, border assemblages, first of all, serve the traditional purpose of protecting the territorial integrity of the host nation. Above all, border control is supposed to deny insurgents cross-border support and sanctuary (Celeski, 2006: 51). But, border assemblages do not just aim to demarcate and protect the host-nation territory: counterinsurgents also seek to configure hostnation space in such a way as to be able to separate the civilian population from the insurgents. Such practices have a profoundly imperialist genealogy. They were, in fact, a staple of 20thcentury British imperial policing and French counter-revolutionary warfare, as well as US counterinsurgency efforts in Vietnam (see Galula, 1964; Marshall, 2010; McClintock, 1992; Townshend, 1986; Tyner, 2009: 97-104).

According to Alex Marshall (2010), the practices of British imperial policing and French counter-revolutionary warfare had a huge influence on the formation of contemporary counterinsurgency doctrine. Many counterinsurgency enthusiasts today tout the British practice of imperial policing as a viable model for current campaigns (see Crawshaw, 2007; Nagl, 2005). As Michael Crawshaw puts it in a paper published by the UK Defence Academy:

The 'British Model', tied as it is to the era of colonial counter-revolutionary war and earlier, is dated. Nevertheless, much of its methodology can be applied to modern insurgencies provided that there is a legitimate indigenous government capable of taking ownership of the campaign. (Crawshaw, 2007: 31 emphasis in original)

Especially the so-called hearts-and-minds approach to counterinsurgency, which the British are widely held to have pioneered, is frequently heaped with praise in the counterinsurgency literature (see Long, 2006: 21-3). ${ }^{4}$ 
The French model of counter-revolutionary warfare, moreover, differed from British imperial policing only in the extent 'to which it sought not to maintain or manage the existing status quo, but rather to actively physically and mentally transform the societies concerned, in order to produce more loyal clients' (Marshall, 2010: 242; emphasis in original). In the words of French veteran and counterinsurgency expert, David Galula (1964: 95), whose work also heavily informed the current US Counterinsurgency Field Manual, 'the basic mechanism of counterinsurgency warfare ... can be summed up in a single sentence: Build (or rebuild) a political machine from the population upwards'.

French policy centred on isolating the insurgents from the population. To this end, French counterinsurgent forces sought to divide operational space into colour-coded zones, physically marked by fences, watchtowers, travel restrictions and infantry patrols: white for government-controlled areas; pink for contested zones; and red for insurgent-controlled areas. Accordingly, the task of the counterinsurgents was to turn pink areas white and red areas first pink and then white (Galula, 1964: 49; Marshall, 2010: 243).

A strikingly similar approach was adopted during the 'surge' in Iraq: the cities of Baghdad and Ramadi were divided into sectors that 'were subjected to intense yet discriminate infantry operations and were cordoned off with checkpoints and barriers; the population was issued identity cards, and any travel to and from the area was strictly controlled' (Ucko, 2009: 128). Officers frequently referred to these fenced-in neighbourhoods as 'gated communities' (Brulliard, 2007; Kilcullen, 2007). In his characteristic penchant for medical tropes, Kilcullen (2007) contends that, 'Gated Communities in counterinsurgency are like tourniquets in surgery' - an effective, or so he claims, albeit somewhat painful, instrument for breaking the cycle of violence. He suggests that the 'gated communities' approach can achieve this aim in three ways:

First, it makes it much harder for terrorists to infiltrate a community. We only establish perimeter security (checkpoints, T-walls, etc.) once the area has been cleared and secured, close relations are established with the population, and we have troops on the ground securing the district in conjunction with the people. Once the gated community goes in, this makes it much harder for extremists to re-enter.

Second, the perimeter controls make it much harder for terrorists to launch attacks from within that district, because they have to smuggle a car bomb or suicide vest out, through a limited number of controlled access points. This reduces extremists' ability to use gated districts as a base to attack neighboring areas.

Third, if the terrorists do manage to mount an attack, the security controls protect the gated community against retaliation by 'death squads'. This reduces fear within the community, alienates extremists from the population (since they can no longer pose as defenders) and emboldens people, who would otherwise be too intimidated, to tip off the security forces to enemy presence (Kilcullen, 2007).

Kilcullen's account of gated communities in Iraq shows that once an area is cleared of insurgents, the population is subjected to a border regime so that the insurgents can be kept out. This regime takes the form of a complex assemblage of technologies (technologies of command, control, communication, surveillance and reconnaissance; biometrics; but also fences, walls, checkpoints, etc.), modes of knowledge production (gathering of census data; mapping the physical and human terrain; etc.), organizations (US and allied military units; host-nation security forces; international aid organizations; etc.) and tactics (saturation patrols; raids; searches and seizures; enlisting the help of the local community; etc.), geared towards permanently pacifying previously cleared spaces. 
Pacification efforts in counterinsurgency bear a closer resemblance to the high-intensity, and often also oppressive, policing of domestic crime hotspots than to conventional military operations. According to one RAND corporation analyst, "pacification is best thought of as a massively enhanced version of the "community policing" technique that emerged in the 1970s (encouraged in part by RAND research)' (Long, 2006: 53). Indeed, in counterinsurgency operations, 'lowintensity warfare meets high-intensity policing' (Hardt and Negri, 2004: 14-15).

In counterinsurgency, the installation of border assemblages is seen as an important step towards (re)building the infrastructure, or what Galula (1964: 95) called the 'political machine', necessary to permanently pacify and stabilize ungoverned spaces:

Population security, is the first requirement of success in counterinsurgency, but is not sufficient. Economic development, good governance, and the provision of essential services within a matrix of effective information operations, must all improve simultaneously and steadily over a long period of time if America's determined insurgent enemies are to be defeated (Nagl, 2007: xix).

Current US doctrine seeks to rehabilitate older imperial, and highly oppressive, practices of population security, and to harness them to the imperatives of a new biopolitical imperialism that is not limited by the geostrategic objectives of individual nation-states, but rather driven by the potentially unlimited aims of promoting life while securing it from its own inherent threats.

\section{Conclusion}

Cutting across the fields of liberal war and liberal rule, counterinsurgency doctrine aims to promote certain forms of species-life while combating those that are deemed dangerous. Counterinsurgency doctrine seeks to articulate security and development into a governmental programme for pacifying spaces and populations that are viewed as threats to the international system of (liberal) states, in order to eventually (re)integrate them into the networks of liberal governance. This programme has been designed and deployed in response to problematizations of (in)security that are both biopolitical and geostrategic. In fact, the very distinction between discourses of human security and US national security is meaningless in a security environment held to be marked by the global circulation of threats emanating from ungoverned spaces.

Counterinsurgency is set to triage between lives that need to be promoted and lives that need be destroyed within spaces and populations that have already been designated as dangerous by the global triage of liberal governance (Dillon and Reid, 2009: 91-4). What is more, the triage of targeted populations is conducted on the basis of Orientalist modes of knowledge (production) and implemented through oppressive population-security measures that derive from the methods of imperial policing.

However, the use of such oppressive regimes of practices will likely continue to swell the ranks of 'accidental guerrillas', who see themselves as merely resisting foreign imperialist occupation, and will ultimately exacerbate the very symptoms of violence that counterinsurgency professes to be able to cure. Because of its biopolitical tendency to pathologize and depoliticize certain forms of violence, and despite its professed aim to address the legitimate grievances of targeted populations, counterinsurgency is unable to acknowledge the genuinely political grievance of foreign military occupation. And foreign occupation will likely breed more resentment and cause further instability that can easily spread across and beyond affected regions. The spread of instability, in turn, will only reinforce Western problematizations of human insecurity and may thus incite Western policymakers to embark on further pacification campaigns in the future. In short, 
counterinsurgency doctrine is not so much a programme of global peace and stability as one of spatially and temporally indeterminate pacification. In fact, what was first known as the 'war on terror' and was then rebranded as the 'Long War' is now also often referred to as 'Global Counterinsurgency’ or GCOIN (Bacevich, 2010; see also Kilcullen, 2005, 2009; Nagl, 2007).

Counterinsurgency's (re)production of divisions between lives that are viewed as safe and those that are seen as threatening is perfectly in line with the broader discourse of human security. With their references to 'bad neighbourhoods', liberal proponents of human security, such as Mary Kaldor, also (re)produce divisions between 'good' liberal cosmopolitans and their 'evil' illiberal Others that can easily be colonized by more explicitly racialized discourses (see Kaldor, 1999, 2003; Glasius and Kaldor, 2005; Kaldor and Beebe, 2010). This, in fact, is a consequence of a biopolitical logic 'disposed to favour some aspects of the species over others' (Dillon and Reid, 2009: 49). And, ultimately, this disposition is what drives biopolitical imperialism and its programmes of global pacification.

\section{Acknowledgements}

The author would like to thank Harald Wenzel, Harald Weigl, the editor and three anonymous reviewers for their insightful comments on earlier versions of this article.

\section{Notes}

1. General McChrystal resigned (or was sacked) as commander of US and NATO forces in Afghanistan in July 2010 after disparaging remarks made by him and his staff about their civilian leaders appeared in a controversial Rolling Stone article (see Hastings, 2010). McChrystal was replaced by General David Petraeus, who is considered one of the chief architects of current US counterinsurgency doctrine.

2. Marja was repeatedly referred to as a town in the Western media. US investigative journalist Gareth Porter (2010), however, pointed out that Marja 'was an agricultural area whose population of about 35,000 was spread over some 120 square kilometres'. This is also borne out by Google Maps' satellite views of the area.

3. David Price revealed that the definitions of basic social science terms in Chapter Three of the manual, entitled 'Intelligence in counterinsurgency', were based on 'pilfered scholarship'. Apparently, the manual has 'borrowed' terms, phrases and even entire paragraphs from a large number of unacknowledged sources (see Price, 2009, 2007).

4. However, Marshall (2010: 241) argues that British imperial policing was not nearly as focused on the 'hearts and minds' of the population as some of its contemporary adherents claim: 'In practice, British methods remained above all reliant upon the threat of the maximum use of force, and included such techniques as crowd control via the use of indiscriminate volley fire, ethnic displacement, mass floggings and torture, the poisoning of wells and burning of villages, the napalm area bombing of Malayan forests, and the creation of "free fire" zones - all conducted under extremely permissive legal constraints.'

\section{References}

Albro R et al. (2009) AAA Commission on the Engagement of Anthropology with the US Security and Intelligence Communities (CEAUSSIC): Final report on the army's Human Terrain System Proof of Concept program.14 October 2009. Available at: http://www.aaanet.org/issues/policy-advocacy/CEAUSSICReleases-Final-Report-on-Army-HTS-Program.cfm (accessed 9 March 2010).

Bacevich AJ (2010) Washington Rules: America's Path to Permanent War. New York: Metropolitan. Barnett T (2004) The Pentagon's New Map: War and Peace in the Twenty-First Century. New York: Berkley. BBC (2010a) Operation Moshtarak: Assault in Helmand province. BBC News, 13 February. Available at: http://news.bbc.co.uk/2/hi/south_asia/8500903.stm (accessed 15 February 2010). 
BBC (2010b) Taliban bombs 'slow Afghan push'. BBC News, 14 February. Available at: http://news.bbc. co.uk/2/hi/south_asia/8515141.stm (accessed 15 February 2010).

Blaufarb D (1977) The Counterinsurgency Era: U.S. Doctrine and Performance 1950 to the Present. New York: The Free Press.

Brulliard, K (2007) 'Gated communities' for the war-ravaged. Washington Post, 23 April. Available at: http:// www.washingtonpost.com/wp-dyn/content/article/2007/04/22/AR2007042201419.html (accessed 1 February 2010).

Cassidy R (2006) Counterinsurgency and the Global War on Terror: Military Culture and Irregular War. Westport, CT: Praeger Security International.

Celeski J (2006) Attacking insurgent space: Sanctuary denial and border interdiction. Military Review 86(6): 51-57.

Clemis M (2009) Crafting non-kinetic warfare: The academic-military nexus in US counterinsurgency doctrine. Small Wars \& Insurgencies 20(1): 160-184.

Commission on Human Security (2003) Human Security Now. Available at: http://www.humansecurity-chs. org/finalreport/index.html (accessed 20 May 2010).

Crawshaw M (2007) Running a country: The British colonial experience and its relevance to present day concerns. Shrivenham Papers 3. Available at: http://www.da.mod.uk/colleges/arag/document-listings/ monographs/shrivenham_paper_3.pdf/view (accessed 28 July 2010).

De Larrinaga M and Doucet MG (2008) Sovereign power and the biopolitics of human security. Security Dialogue 39(5): 517-537.

Dean M (1999) Governmentality: Power and Rule in Modern Society. Thousand Oaks, CA: Sage.

Dillon M and Neal A (eds) (2008). Foucault on Politics, Security and War. London: Palgrave.

Dillon M and Reid J (2009) The Liberal Way of War: Killing To Make Life Live. London: Routledge.

Duffield M (2003) Social reconstruction and the radicalization of development: Aid as a relation of global liberal governance. In: Millikan J (ed.) State Failure, Collapse and Reconstruction. Oxford: Blackwell, 291-312.

Duffield M (2005) Getting savages to fight barbarians: Development, security and the colonial present. Conflict, Security and Development 5(2): 141-159.

Duffield M (2007) Development, Security and Unending War: Governing the World of Peoples. Cambridge: Polity.

Duffield M (2008) Global civil war: The non-insured, international containment and post-interventionary society. Journal of Refugee Studies 21(2): 145-165.

Duffield M (2010) The liberal way of development and the development-security impasse: Exploring the global life-chance divide. Security Dialogue 41(1): 53-76.

Edkins J, Pin-Fat V and Shapiro M (eds) (2004) Sovereign Lives: Power in Global Politics. London: Routledge.

Evans B (2010) Foucault's legacy: Security, war and violence in the 21st century. Security Dialogue 41(4): 413-433.

Feldman A (2004) Securocratic wars of public safety. Interventions: The International Journal of Postcolonial Studies 6(3): 330-350.

Feldman G (2009) Radical or reactionary? The old wine in the Counterinsurgency Field Manual's new flask. In: Network of Concerned Anthropologists (eds) The Counter-Counterinsurgency Manual or, Notes on Demilitarizing American Society. Chicago, IL: Prickly Paradigm Press, 77-93.

Finney N (2008) Human Terrain Team Handbook. September 2008. Available at: http://www.scribd.com/ doc/8959317/Human-Terrain-Handbook-2008 (accessed 9 February 2010).

Foucault M (2000) The subject and power. In: Faubion JD (ed.) Power. New York: The New Press, 326-348. 
Foucault M (2003) Society Must Be Defended: Lectures at the College de France 1975-1976. Translated by David Macey. New York: Picador.

Foucault M (2007) Security, Territory, Population: Lectures at the College de France 1977-1978. Translated by Graham Burchell. Basingstoke: Palgrave Macmillan.

Galula D (1964) Counterinsurgency Warfare: Theory and Practice. Westport, CT: Praeger Security International. Gardner F (2010) Afghan Operation Moshtarak places success over surprise. BBC News, 8 February. Available at: http://news.bbc.co.uk/2/hi/south_asia/8505179.stm (accessed 15 February 2010).

Giddens A (1987) The Nation State and Violence. Berkeley, CA: University of California Press.

Glasius M and Kaldor M (eds) (2005) A Human Security Doctrine for Europe. London: Routledge.

González RJ (2007) Towards mercenary anthropology? The new US Army counterinsurgency manual $F M$ 3-24 and the military-anthropology complex. Anthropology Today 23(3): 14-19.

González RJ (2009a) Embedded: Information warfare and the 'human terrain'. In: Network of Concerned Anthropologists (eds) The Counter-Counterinsurgency Manual or, Notes on Demilitarizing American Society. Chicago, IL: Prickly Paradigm Press, 97-113.

González RJ (2009b) American Counterinsurgency: Human Science and the Human Terrain. Chicago, IL: Prickly Paradigm Press.

González RJ, Gusterson H and Price D (2009) Introduction. In: Network of Concerned Anthropologists (eds) The Counter-Counterinsurgency Manual, or Notes on Demilitarizing American Society. Chicago, IL: Prickly Paradigm Press, 1-20.

Gregory D (2008) 'The rush to the intimate': Counterinsurgency and the cultural turn. Radical Philosophy 150: 8-23.

Gregory D (2010) Seeing red: Baghdad and the event-ful city. Political Geography 29(5): 266-279.

Hammes TX (2006) The Sling and the Stone: On War in the 21st Century. Minneapolis, MN: Zenith.

Hardt M and Negri A (2004) Multitude: War and Democracy in the Age of Empire. London: Penguin.

Hastings M (2010) The runaway general. Rolling Stone, 8-22 July. Available at: http://www.rollingstone.com/ politics/news/17390/119236 (accessed 5 August 2010).

Hettne B (2010) Development and security: Origins and future. Security Dialogue 41(1): 31-52.

Hilsman R (1967) To Move a Nation: The Politics of Foreign Policy in the Administration of John F. Kennedy. New York: Doubleday.

Kaldor M (1999) New and Old Wars: Organized Violence in a Global Era. Stanford, CA: Stanford University Press.

Kaldor M (2003) American power: From 'compellance' to cosmopolitanism? International Affairs 79(1): $1-22$.

Kaldor M and Beebe SD (2010) The Ultimate Weapon is No Weapon: Human Security and the New Rules of War and Peace. New York: Public Affairs.

Kennedy JF (1961) 'The president and the press'. Address before the American Newspaper Publishers Association, New York City, 27 April 1961. Available at: http://www.jfklibrary.org/Research/ReadyReference/JFK-Speeches/The-President-and-the-Press-Address-before-the-American-NewspaperPublishers-Association.aspx (accessed 15 August 2011).

Kienscherf M (2010) Plugging cultural knowledge into the U.S. military machine: The neo-orientalist logic of counterinsurgency. Topia: Canadian Journal of Cultural Studies 23-24: 121-143.

Kilcullen DJ (2005) Countering global insurgency. Journal of Strategic Studies 28(4): 597-617.

Kilcullen DJ (2007) The urban tourniquet: 'Gated communities' in Baghdad. Small Wars Journal. Available at: http://smallwarsjournal.com/blog/2007/04/the-urban-tourniquet-gated-com/ (accessed 1 February 2010).

Kilcullen DJ (2009) The Accidental Guerrilla: Fighting Small Wars in the Midst of a Big One. Oxford: Oxford University Press. 
Kipp J, Grau L, Prinslow K and Smith D (2006) The Human Terrain System: A CORDS for the 21st Century. Military Review 86(5): 8-15.

Larner W and Walters W (2004) Introduction. In: Larner W and Walters W (eds) Global Governmentality: Governing International Spaces. London: Routledge, 1-20.

Lemke T (2000) Foucault, governmentality, and critique. Paper presented at the conference Rethinking Marxism, 21-24 September, University of Massachusetts Amherst.

Long A (2006) On 'Other War': Lessons from Five Decades of RAND Counterinsurgency Research. Santa Monica, CA: RAND Corporation.

Lyon D (2008) Filtering flows, friends, and foes. In: Salter MB (ed.) Politics at the Airport. Minneapolis, MN: University of Minnesota Press, 29-49.

McChrystal SA (2009) COMISAF's initial assessment. Secretary of Defense memorandum, 11 March. Available at: http://media.washingtonpost.com/wp-srv/politics/documents/Assessment_Redacted_092109. pdf?hpid=topnews (accessed 21 September 2009).

McClintock M (1992) Instruments of Statecraft: U.S. Guerrilla Warfare, Counter-Insurgency, and CounterTerrorism, 1940-1990. New York: Pantheon.

McFalls L (2010) Benevolent dictatorship: The formal logic of humanitarian government. In: Fassin D and Pandolfi M (eds) Contemporary States of Emergency: The Politics of Military and Humanitarian Interventions. New York: Zone Books, 317-333.

McFate M (2005a). Anthropology and counterinsurgency: The strange story of their curious relationship. Military Review 85(2): 24-38.

McFate M (2005b) The military utility of understanding adversary culture. JFQ: Joint Force Quarterly 38: 42-8.

McFate M and Jackson A (2006) The object beyond war: Counterinsurgency and the four tools of political competition. Military Review 86(5): 56-69.

Makaremi C (2010) Utopias of power: From human security to the responsibility to protect. In: Fassin D and Pandolfi M (eds) Contemporary States of Emergency: The Politics of Military and Humanitarian Interventions. New York: Zone Books, 107-127.

Manwaring MG (2005) The new global security landscape: The road ahead. In: Bunker RJ (ed.) Networks, Terrorism and Global Insurgency. London and New York: Routledge, 20-39.

Marshall A (2010) Imperial nostalgia, the liberal lie, and the perils of postmodern counterinsurgency. Small Wars \& Insurgencies 21(2): 233-258.

Miller P and Rose N (2008) Governing the Present: Administering Economic, Social and Personal Life. Cambridge: Polity.

Mullen M (2010) JCS Speech. Tel Aviv Press Conference, 26 March: Available at: http://www.jcs.mil/speech. aspx?id=1326 (accessed 14 February 2010).

Nagl JA (2005) Learning To Eat Soup with a Knife: Counterinsurgency Lessons from Malaya and Vietnam. Chicago, IL: University of Chicago Press.

Nagl JA (2007) Foreword to the University of Chicago Press edition. In: The U.S. Army/Marine Corps Counterinsurgency Field Manual. Chicago, IL: University of Chicago Press, xiii-xx.

Porter G (2010) McChrystal faces massive failure in Afghanistan in next few months. IPS News, 13 June 2010. Available at: http://www.alternet.org/story/147190/mcchrystal_faces_massive_failure_in_afghanistan_in_ next_few_months/ (accessed 16 August 2010).

Price D (2007) Pilfered scholarship devastates General Petraeus's Counterinsurgency Manual. Counterpunch, 30 October. Available at: http://www.counterpunch.org/price10302007.html (accessed 11 March 2010).

Price D (2009) Faking scholarship: Domestic propaganda and the republication of the Counterinsurgency Field Manual. In: The Network of Concerned Anthropologists (eds) The Counter-Counterinsurgency Manual or, Notes on Demilitarizing American Society. Chicago, IL: Prickly Paradigm Press, 59-76. 
Renzi F (2006) Networks: Terra incognita and the case for ethnographic intelligence. Military Review 86(5): $16-22$.

Rose N and Miller P (1992) Political power beyond the state: Problematics of government. British Journal of Sociology 43(2): 173-205.

Sahlins M (2009) Preface. In: Network of Concerned Anthropologists (eds) The Counter-Counterinsurgency Manual or, Notes on Demilitarizing American Society. Chicago, IL: Prickly Paradigm Press, i-vii.

Said E (1979) Orientalism. New York: Vintage.

Salter MB (2005) At the threshold of security: A theory of international borders. In: Zureik E and Salter MB (eds) Global Surveillance and Policing: Borders, Security, Identity. Portland, OR: Willan, 36-50.

Salter MB (2008a) Introduction: Airport assemblage. In Salter MB (ed.) Politics at the Airport. Minneapolis, $\mathrm{MN}$ : University of Minnesota Press, ix-xix.

Salter MB (2008b) The global airport: Managing space, speed, and security: In Salter MB (ed.) Politics at the Airport. Minneapolis, MN: University of Minnesota Press, 1-28.

Sewall S (2007) Introduction to University of Chicago Press Edition. In: The U.S. Army/Marines Counterinsurgency Field Manual. Chicago, IL: University of Chicago Press, xxi-liv.

Shafer MD (1988) Deadly Paradigms: The Failure of U.S. Counterinsurgency Policy. Princeton, NJ: Princeton University Press.

Slim H (2004) With or against? Humanitarian agencies and coalition counter-insurgency. Geneva: Centre for Humanitarian Dialogue. Available at: http://www.hdcentre.org/files/With\%20or\%20Against\%20.pdf (accessed 16 February 2010).

Stern M and Öjendal J (2010) Mapping the security-development nexus: Conflict, complexity, cacophony, convergence? Security Dialogue 41(1): 5-29.

Townshend C (1986) Britain's Civil Wars: Counterinsurgency in the Twentieth Century. London: Faber and Faber.

Tran T (2010) UN officials criticize 'militarization' of humanitarian aid in Afghanistan. The Canadian Press, 18 February. Available at: http://www.google.com/hostednews/canadianpress/article/ALeqM5gtxb4h8nGg0KtJ9dTqjBedRHsMAg (accessed 24 February 2010).

Tyner J (2009) War, Violence, and Population: Making the Body Count. New York: The Guilford Press.

Ucko DH (2009) The New Counterinsurgency Era: Transforming the U.S. Military for Modern Wars. Washington, DC: Georgetown University Press.

US Department of the Army (2007) The U.S. Army/Marine Corps Counterinsurgency Field Manual. Chicago, IL: University of Chicago Press.

US Department of Defense (2010) Quadrennial Defense Review Report. Washington, DC: Department of Defense. Available at: http://www.defense.gov/QDR/ (accessed 1 May 2010).

US Government (1962). United States Overseas Internal Defense Policy, September 1962. Available at: http:// www.scribd.com/doc/50366332/Overseas-Internal-Defense-Policy-1962' (accessed 18 August 2011).

Von Clausewitz C (1976) On War. Princeton, NJ: Princeton University Press.

Weizman E (2007) Hollow Land: Israel's Architecture of Occupation. London: Verso.

Markus Kienscherf has recently earned his doctorate in sociology from Free University Berlin. He is currently working on a research monograph about the intersections between US domestic and international security. 